appropriate Ministry of Supply research establishments. At the next level, the technical reconnaissance officers are in the headquarters section of the local division so that, as Sir John Hodsoll had explained, they are part of the local authority's organization and must in the long run be recruited through that machinery, though he would take note of the diffculties mentioned. The plea for full technical information was one with which every scientist would sympathize; though there is no secrecy in civil defence as such, it has to be recognized that information of a secret nature is used in the Home Office in the study of civil defence problems, so that it is not possible to pass on some kinds of information. From his own experience, he agreed with the principle that secret information should be given only to those who must have it in order to carry out their duties. $\mathrm{He}$ did not think there is any greater likelihood of an epidemic resulting from biological warfare attack after an attack with high explosives than in other circumstances. In any event it is necessary to guard against the tendency to conjure up complicated defence problems by piling one form of attack on another. A very great effort is required to deliver a modern attack on an effective scale, and any complication of the kind suggested must reduce the effectiveness of the first attack without greatly increasing the chance of the second attack being more effective than if it had been delivered alone on the appropriate scale.

Suggestions had been made about the possibility of the atomic bomb being 'played down' unjustifiably, and in particular a question was asked how this could be reconciled with the casualty figures published after the visit of the British Mission to Japan. There was no intention of minimizing the potentialities of the bomb; but what had been attempted was to show how the number of resultant casualties might vary in different circumstances. For example, if it was assumed that an unwarned attack on a city with the population all exposed in the open would result in, say, 50,000 casualties, then it could be shown that if everybody was in houses of an assumed standard of construction the casualties would be reduced to 30,000 under the same attack; and again, if they were all in special shelters of a specified standard of protection, the casualties would fall to 10,000 .

In conclusion, Dr. Paris said the discussion had served a most useful purpose in providing evidence of the kind of difficulties that might arise in setting up the reconnaissance service, and of the lines on which interested scientists were thinking on these matters. Since the meeting, he has agreed to consider the problem in consultation with the three Institutes which organized the discussion.

J. W. Martin

\section{THE ALEMBIC CLUB}

\section{By Prof. JAMES KENDALL, F.R.S.}

$\mathrm{O}^{\mathrm{N}}$ October 29, 1889, the five non-professorial members of the teaching staff of the Chemistry Department in the University of Edinburgh formed themselves, under the title of "The Alembic Club", into "an unassuming body which was destined later to play a useful part in bringing historical material connected with chemistry within the reach of interested readers". In order of seniority, the original members of the Club were:
1. John Gibson. The originator, with Prof. Crum Brown, of the famous Crum Brown-Gibson rule for determining the position of radicals entering a substituted benzene nucleus. Professor of chemistry in the Heriot-Watt College, Edinburgh, 1892. Died in 1914 .

2. Leonard Dobbin. Distinguished for his research work in the history of chemistry and for his translations of Ladenburg's "Lectures on the History of the Development of Chemistry since the time of Lavoisier" (1900) and Scheele's "Collected Papers" (from Swedish and German originals, 1931). He was lecturer in chemistry in the University of Edinburgh, 1914 ; reader, 1920. Dr. Dobbin died in March 1952 in his ninety-fourth year. For seventy-one years he was a Fellow of the Royal Society of Edinburgh (Member of Council 1904-7 and 1913-16, Curator 1934-39, Vice-president 1939-42) and for more than sixty years a Fellow of the Chemical Society and the Society of Chemical Industry. Secretary of the Alembic Club from its inception to 1946 , he was its guiding spirit throughout that long period.

3. Hugh Marshall. Discoverer of the persulphates ; elected a Fellow of the Royal Society in 1904. After holding a lectureship in crystallography in the University of Edinburgh, he was appointed to the chair of chemistry in University College, Dundee, in 1908 ; he died in 1913.

4. James Walker. For many years the leading physical chemist of Great Britain. Professor of chemistry in University College, Dundee, 1894-1908, and in the University of Edinburgh, 1908-28. He was awarded the Davy Medal of the Royal Society in 1926, and the Gunning Victoria Jubilee Prize of the Royal Society of Edinburgh in 1932. President of the Chemical Society, 1921-23. Knighted in 1921 and died in 1935.

5. Alexander Smith. Famous for his research work on the allotropic forms of sulphur and for his series of text-books on inorganic and physical chemistry. Professor of chemistry in Wabash College, Indiana, 1890-94, in the University of Chicago 18941911, and head of the department of chemistry in Columbia University, New York, 1911-20. President of the American Chemical Society, 1911. Died in 1922 .

Members elected afterwards were :

6. Ralph Stockman (1891). Professor of materia medica in the University of Glasgow, 1897-1936. Elected a Fellow of the Royal Society in 1889. Vice-President of the Royal Society of Edinburgh, 1939 42. Died in 1946 .

7. James Kendall (1929). Professor of chemistry in Columbia University, 1914-26, in New York University, 1926-28, and in the University of Edinburgh, 1928 to date. Secretary of the Alembic Club since 1946.

8. Irvine Masson (1932). Professor of chemistry, University of Durham, 1924--38 ; vice-chancellor of the University of Sheffield, 1938-52. Knighted in 1950.

9. Oswald James Walker (1937). Formerly lecturer in chemistry, University College, London, now on the staff of Imperial Chemical Industries, Ltd. (Plastics Division), Welwyn Garden City.

At a very early stage in the existence of the Club, the important resolve was taken to publish some of the less easily accessible chemical classics in convenient form, as simple reprints (if in English) or as translations (if in a foreign language). It was fitting that the first of these "Alembic Club Reprints" should present in 1893 Joseph Black's world- 
renowned "Experiments on Magnesia Alba, etc.", in view of the author's occupancy for many years of the chair of chemistry in the University of Edinburgh. Succeeding reprints were: (2) "Foundations of the Atomic Theory", by Dalton, Wollaston and Thomson; (3) "Experiments on Air", by Cavendish; (4) "Foundations of the Molecular Theory", by Dalton, Gay-Lussac and Avogadro; (5) "Extracts from Micrographia", by Hooke; (6) "The Decomposition of the Alkalis and Alkaline Earths", by Davy ; (7) "The Discovery of Oxygen", Part I, by Priestley ; (8) "The Discovery of Oxygen", Part II, by Scheele; (9) "The Elementary Nature of Chlorine", by Davy ; (10) "Researches on the Arseniates, etc", by Graham ; (11) "Essays of Jean Rey" ; (12) "The Liquefaction of Gases", by Faraday ; (13) "The Early History of Chlorine", by Scheele and others ; (14) "The Molecular Asymmetry of Natural Organic Products", by Pasteur; (15) "The Electrolysis of Organic Compounds", by Kolbe ; (16) "Papers on Etherification, etc". by Williamson; (17) "MedicoPhysical Works", by Mayow ; (18) "Sketch of a Course of Chemical Philosophy", by Cannizzaro ; (19) "The Foundations of the Theory of Dilute Solutions", by Van't Hoff and Arrhenjus; (20) "Prout's Hypothesis", by Prout, Stas and Marignac; and (21) "On a New Chemical Theory, etc.", by Couper.

These twenty-one "Alembic Club Reprints" have enjoyed a steady sale (totalling more than 32,000 ) throughout the decades, and have undoubtedly proved of inestimable service to teachers, students and research workers in the domain of historical chemistry. They are issued by the Club's agents-E. and S. Livingstone, Teviot Place, Edinburgh - at a price just above the cost of publication, profits being deliberately restricted to a point that will permit the periodic replenishment of stock as particular numbers niear exhaustion. No. 17 only is now out of print, becauso of its special expense.

In the months immediately preceding his death, Dr. Dobbin - frail in body, but with mind alert and unimpaired-- became apprehensive as to the future of the Alembic Club, and the present secretary knew that he was acting as Dr. Dobbin himself would have desired when, with the approval of the other two surviving members, he proposed to the Council of the Royal Society of Edinburgh that the Council should accept the entire assets of the Club and the responsibility for the continuance of its series of reprints. This offer was cordially accepted by the Council on July 7,1952 , the general opinion being expressed that it would appear desirable not only to continue the existing reprints but also to extend the series by new issues of a similar nature in chemistry and adjoining fields of science. A committee was appointed, consisting of the president, the general secretary and the treasurer, to submit recommendations for the administration of the "Alembic Club Fund" on a broader and firmer basis under the ægis of the Royal Socjety of Edinburgh.

Before the Club passed under new management, however, its members decided to add to their number Norman Feather, professor of natural philosophy in the University of Edinburgh, in the hope that a precedent would thus be established ensuring the perpetuity of the Alembic Club within the Society.

The report of the Committee, approved by the Council on October 27, 1952, contained in fact a clause recommending that the Alembic Club should persist as a self-perpetuating body, fortified by the inclusion of the senior officers of the Society. Other recommendations were that an Alembic Club Prize of $£ 50$ should be awarded to a distinguished historian of science quinquennially, provided funds for it were sufficient, and that Alembic Club Lectures should be delivered at unspecified intervals. The first of such lectures will be formally entitled the Leonard Dobbin Memorial Lecture.

\section{INTERNATIONAL COUNCIL OF SCIENTIFIC UNIONS}

\section{GENERAL ASSEMBLY IN AMSTERDAM}

HE sixth general assembly of the International Council of Scientific Unions was held in the rooms of the Koninklijke Nederlandse Akademie van Wetenschappen in Amsterdam during October 1-3. Twenty countries were represented. Prof. H. R. Kruyt, president of the Division of Sciences of the Academy and a former president of the Council, welcomed the assembly on behalf of the Academy. He spoke of the importance of the work of the Unions with their freedom to organize scientific discussions unhampered by administrative and political influences, and pointed out that he has a special regard for the Council, having attended every meeting since 1922 .

The president of the Council, Prof. A. von Mura]t (Switzerland), thanked Prof. Kruyt for his welcome and the Netherlands Academy for its hospitality and help in arranging the meeting. He explained how his three years experience as president have given him a great respect for the Council and some of its activities; joint commissions, symposia, support of laboratories of international standing and of established scientific services, all are of great value at the present time. The Council owes a great debt to the United Nations Educational, Sciontific and Cultural Organization (Unesco) for its financial ajd, and it is glad to help the Organization to carry out part of its task ; Prof. Muralt also acknowledged the help given throughout by Prof. Pierre Auger (head of the Natural Sciences Division of Unesco) and his staff. International congresses have begun to grow too large, partly owing to the great increase in the number of scientific workers and the rapid growth of fresh branches of science, and the point is being reached where the present organization is becoming inadequate. One must not be too reluctant to see new Unions formed, but this must lead to difficulties in the co-ordination by a central body. There must come a time when some federal groups should be formed, intermediate between the Council and its individual Unions. He felt obliged to mention one activity of the Council, namely, the starting of an abstracting board to help in improving what has become in many sciences a difficult situation. A limit has been set at first to one subject - physies (see p. 954 of this issue). One result of improved co-ordination between existing abstracting journals has been a considerable speeding-up of the publication of abstracts.

After a tribute to the work of the Council and its Unions on the scientific side, Prof. Auger pointed out a gap between the purely scientific aspects and the financial and administrative ones. Those responsible for the latter side, he said, do not always understand the needs of those responsible for the former. One 